\title{
Akışkan Bir İslam Hukukuna Doğru: Modernite ve Makasıd Söyleminin Dönüşümü*
}

\author{
Muhammed MERÂKİB̂̂ \\ Dr., Edinburg Üniversitesi, m.almarakiby@yahoo.com,
}

\section{Yasin YILMAZ}

Arş. Grv., Necmettin Erbakan Üniversitesi, Hukuk Fakültesi, yasinyilmazz@yahoo.com

\section{Çevirenler}

\section{Enes CÖMERT}

Yüksek Lisans Öğr., İbn Haldun Üniversitesi, Uluslararası ve Mukayeseli Hukuk, enescomert4@gmail.com

\begin{tabular}{|c|c|}
\hline Mal & \\
\hline Makale Geçmişi & \multirow{6}{*}{$\begin{array}{l}\text { Bu makale, müslüman düşünürlerin çağdaş makâsıd söyleminde yaptıkları tecdidi/yenilenmeyi } \\
\text { tartışmaktadır. Aralarındaki ihtilaflara rağmen iki ana gelişme gözlemleyebiliriz; birincisi İslam } \\
\text { hukukunu rasyonelleştirme ve taabbüdî yönünü dışlama veya kaldırma ve ikincisi maksatların yeniden } \\
\text { tayini ile sayılarının ve yorumlarının genişletilmesi temayülüdür. Bu satırların yazarı -makâsıdın yeni } \\
\text { yorumlarının muhtelif modellerini sunarak- modernitenin yeni makâsıd söylemini sadece kavramlarını } \\
\text { benimseterek değil, aynı zamanda akışkan tabiatını da kazandırmak suretiyle nasıl etkilediğini } \\
\text { göstermektedir. Bu husustaki en mühim dönüşüm, makâsıdın esnek ve yapılandırılabilir bir araca } \\
\text { dönüşmesidir. Esasen bu araç, modern değerlere hem yaklaşmak ve hem de onlardan uzaklaşmak için } \\
\text { kullanılabilir. Bahsedilen akışkanlık ile makâsıd, çoğu kez -ister bilinçli ister bilinçsiz olsun- } \\
\text { hukukçuların ideolojik, sosyolojik ve psikolojik önyargılarının bir yansıması haline gelmiştir. Bu } \\
\text { durum da İslam hukukunun sistematik yapısını ve gerekli toplumsal kontrolü sağlama yeteneğini tehdit } \\
\text { etmektedir. }\end{array}$} \\
\hline Yayin: 30 & \\
\hline & \\
\hline Yeni makâsıd ekolü, & \\
\hline & \\
\hline & \\
\hline
\end{tabular}

الحداثة وتحولات الخطاب المقاصدي: نحو فقه سائل؟

\begin{tabular}{|c|c|}
\hline Article Info & Abstract \\
\hline $\begin{array}{l}\text { Article History } \\
\text { Received: } 23.04 .2021 \\
\text { Accepted: } 29.06 .2021 \\
\text { Published: } 30.06 .2021\end{array}$ & 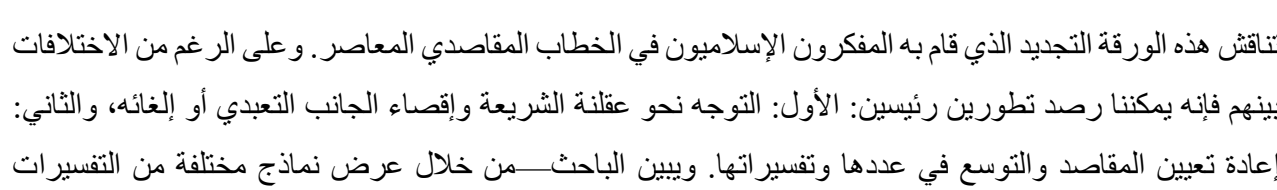 \\
\hline 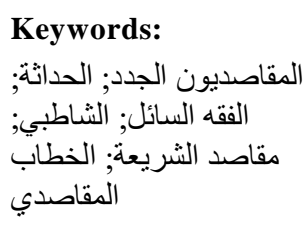 & 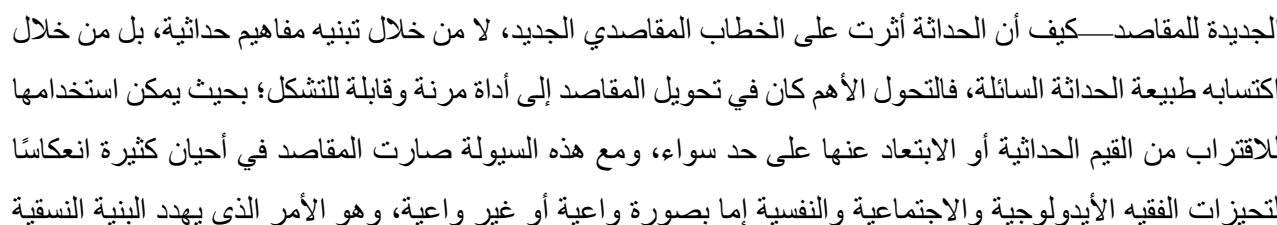 \\
\hline
\end{tabular}

Atıf/Citation: Merâkibî, M. (2021). “Akışkan Bir İslam Hukukuna Doğru: Modernite ve Makasıd Söyleminin Dönüşümü”, çev. Y. Yılmaz \& E. Cömert, Necmettin Erbakan Üniversitesi Hukuk Fakültesi Dergisi, 4(1), s. 305-323.

Plagiarism: Bu makale intihal programında taranmış ve en az iki hakem incelemesinden geçmiştir. // This article has been scanned via a plagiarism software and reviewed by at least two referees.

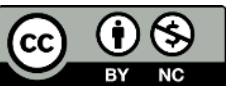

"This article is licensed under a Creative Commons Attribution-NonCommercial 4.0 International License (CC BY-NC 4.0)"

\footnotetext{
* İlmî yorumlarından ve tavsiyelerinden çokça istifade ettiğim Dr. Mu`tez el-Hatib, Dr. Alexandre Caeiro ve Prof. Ahmed Semni ile bu makalenin hakemlerine teşekkür ediyorum. [yazar notu].

İlkin Journal of Islamic Ethics, 3(1-2), 2019, s. 9-29'da yayımlanan makalesinin tercümesine izin veren yazara, böyle bir çeviriyi öneren dostumuz Şükrü Atsızelti'ye ve metnin tashihinde yardımlarını esirgemeyen Bahaddin Karakuş ile Hüseyin Ay’a alenî ve samimî teşekkürâtımızın arzını bir vazife-i vicdaniye biliriz. [çevirmenler notu].
} 


\section{GİRIS}

Son yıllarda makâsıd çalışmaları benzeri görülmemiş bir şekilde yayılmış ve o kadar ki araştırmacılardan birinin makâsıd ile ilgili yazılanları topladığı bir rehber yayımlamak için dokuz cilde ihtiyacı olmuştur. ${ }^{1}$ Bu derleme de sadece Arapça yazılmış çalışmalarla sınırlıdır ve makâsıd çalışmalarında büyük payı olan diğer dillerdeki yayınlara değinilmemiştir. Örneğin Türkiye'de makâsıd üzerine yapılan bir çalışmada yazarlardan biri sadece son yirmi yılda Türkçe'de bu konuda yüzlerce yayının mevcut olduğunu kaydetmiştir. ${ }^{2}$ Avrupa dilleri, Malayca, Urduca ve diğer dillerde yazılanlardan bahsetmiyorum bile. Makâsıd çalışmalarındaki bu sürekli artış, -şüphesizbunların sebepleri, tasavvurları ve gelecekleri hakkında birçok soruyu da gündeme getirmektedir. Modern makâsıd çalışmalarının bolluğuna rağmen, bu yoğun meşguliyete ilişskin tahlilî ve tenkidî çalışmalar, mevcut üretim hacmi göz önüne alındığında beklenen seviyede değildir. ${ }^{3}$ Dolayısıyla bu makale, makâsıd akımı üzerine tahlilî ve tenkidî çalışmalara mütevazı bir katkı sağlamak için yazılmıştır.

İncelenen alanın cesametinden dolayı bu makalenin konusu seküler olmayan düşünürlerin yeni makâsıd söylemlerinin tahlili ile sınırlıdır ve bu sınırlama ile alanda mevcut iki söylem olduğu kabul edilmektedir: Birincisi, seküler/laik düşünürlerin makâsıd söylemi; ${ }^{4}$ ikincisi, kendilerini erken dönem makâsıd alimlerinin ayrılmaz bir devamı olarak gören ve anlayışlarını yenilenme ve gelişme çağrılarından uzak tutan modern çağdaki makâsıd söylemidir. ${ }^{5}$ Çalışma kapsamında, kendilerini her ne kadar erken dönem makâsıd alimlerine nispet etseler de -bununla beraber- eski söylemi bu çağda ayakları sağlam basacak bir şekilde yenilemek ve geliştirmek şiarını yüksek sesle dile getiren çok sayıda düşünürü ele alacağız. Bu makale, Tunuslu Hayreddin (ö. 1890), Muhammed Abduh (ö. 1905) ve Tâhir bin Âşûr'dan (ö. 1973) başlayan; Karadavî, Alvânî (ö. 2016) ve Cemaleddin Atıyye’yle (ö. 2017) devam eden ve Câsir Avde, Tarık Ramazan ve diğerleri ile biten çeşitli ve farklı şahsiyetleri bir araya getirmektedir. Bu makâsıd ekolü arasında -beklendiği üzere- kimi zaman geniş kimi zaman dar boyutlu görüş ayrılıkları olduğu iyi bilinmektedir. Konu edilen makâsıd ekolünün temsilcileri ittifakla tek bir görüşü temsil ettikleri için seçilmemiştir. Çünkü araştırmanın amacı, fıkhî sistem dahilindeki ihtilafların ve farklılıkların mevcudiyeti bir tarafa, bu sistem üzerindeki dönüşümlerin etkisini açıklamaktır.

Araştırma, modernite kavramını, onu tanımlama problemini ve burada murad edilen anlamını tartışan bir mukaddime ile başlar, sonra Şâtıbî’nin (ö. 1388) önceki fıkıh geleneğini sürdürdüğü ve onda radikal bir dönüşüm getirmeyi hedeflemediği meselesine değinir, daha sonra konunun merkezinde yer alan yeni makâsıd ekolünün yaptığı dönüşümleri tasnif etmeyi dener. Bu tasnif iki husus bakımından ortaya çıkar: Makâsıdu'ş-şerî‘a üzerindeki rasyonelleştirme hakimiyeti ve modernite vakıasının ışığında makâsıdın yeniden belirlenmesi ve yorumlanması.

\footnotetext{
${ }^{1}$ Muhammed Kemaleddin İmam, ed-Delilu'l-İrşadiyyu ilâ Makâsıdi'ş-Şerî‘a, Daru'l-Furkan, London 2008-2012.

${ }^{2}$ Aydoğan Kars, "Māqāșid or Sharīa a? Secularism, Islamic Reform, and Ethics in Modern Turkey" in Maqasid alsharia and Contemporary Reformist Muslim Thought: an Examination, edited by Adis Duderija, Palgrave Macmillan, New York 2014.

${ }^{3}$ Aşağıda çalışma arasında bunlardan birkaçına işaret edilecektir.

${ }^{4}$ Makâsıd ile ilgili bazı seküler çalışmaların incelenmesi için örneğin bkz. Ahmed Taân, el-Almaniyyun ve'lKur'anu'l-Kerim, Daru İbn Hazm, Riyad 2007.

5 Örneğin Muhammed Said el-Bûtî'nin fikıh usûlünün yenilenmesi üzerine çalışmasına bkz. Muhammed Said el-Bûtî, Nahve Tecdidi Usûli'l-Fıkh fî İşkaliyyeti Tecdidi Usûli'l-Fıkıh, Daru'l-Fikr, Dımeşk 2006.
} 
Nihayet araştırma, makâsıdın yeniden tanımlanması ve geniş̧letilmesinde karşılaşılan, bu maksatların belirli olmayan akışkan bir yapıya dönüşmesinde görülen ve İslam hukukunun kendisine tahsis edilen toplumsal kontrolü sağlama yeteneğini engelleyen sorunların açıklanmasıyla sona erer.

\section{Modernite: Tanımlanamayanı Tanımlamak?}

Modernite hakkındaki tartışmaların çokluğu karşısında bu terim, en muğlak kavramlardan biri olmaya devam etmektedir ve son yıllarda modernitenin manası üzerine tartışmalar artmış olsa da, bunlar sadece meselenin bulanıklaşmasına yol açmıştır. Modernite genellikle; -bu kavramların her birinin anlamlarında birçok ihtilaf bulunmakla birlikte- modern devlet, kapitalizm, laiklik, araçsal akılcılık ve bireycilik gibi kurum ve ilkelere dayandırılarak tanımlanır. ${ }^{6}$ Yine etimolojisi itibariyle modernite, mekansal ve zamansal bir kopuş olarak da tanımlanabilir; batının dünyanın geri kalanından mekansal kopuşu ve -düşünürler tam tarihte ihtilaf etseler de- on altıncı, on yedinci veya on sekizinci yüzyılla sona eren geleneksel çağlardan zamansal kopuş ile temayüz eder. ${ }^{7}$ Modernitenin tanımlarından bahsetmenin bize, artık genel eğilimin tek bir modernite hakkında düşünmekten çeşitli modernitelere kaydığını idrak ettiğimizde pek bir faydası olmayacaktır. Zamansal açıdan modernite çok farklı şekiller almış, bu kapsamda zamansal olarak ardışık moderniteler, düşük veya yüksek moderniteler ya da Giddens'ın isimlendirdiği gibi radikal moderniteler $^{8}$ veyahut bazılarının post-moderniteye geçiş olarak gördüğü fikirler ${ }^{9}$ ortaya çıkmıştır. Geçen yüzyılın sonlarında da mekan itibariyle batı merkeziyetçiliğine yönelik eleştirel çağrılar yapılmaya başlamıştır.

Modernitenin kökeninde Batılı olarak görülmesine rağmen diğer yerel kültürlerle etkileşimi sayesinde benimseme ve reddetme mekanizmaları aracılığıyla kimi zaman benzeşen, kimi zaman batılı modelinden farklılaşan muhtelif suretlerde moderniteler ortaya çıkmış ve Japon, Çin ve İslam modernitelerinden bahsetmek mümkün hale gelmiştir. ${ }^{10}$ Lakin mesela Batı modernitesi ile İslamî modernite arasındaki bu farklılaşmada evrensel ve yerel olanın sınırlarının nasıl çizileceğine ilişkin tartışmalar devam etmektedir. Çeşitli modernitelerden bahsetmek öncelikle şu soruların yöneltilmesini gerekli kılar: Neden çeşitli?, Bu muhtelif suretlerin kaynağı nedir?, Modernite hususunda neyin sabit neyin değişken olduğuna ve neyin evrensel ve neyin batıya özgü olduğuna kim karar veriyor? ${ }^{11}$ İslamî modernite fikrini benimseyen çalışmaları karşılaştırırsak aralarında büyük farklılıklar bulacağız. İslamî modernite, -Robert Hefner'ın sivil toplum çalışmasıyla ortaya koyduğu gibi- batılı modelinden çok da farklı değildir. ${ }^{12}$ Bunun aksine Batı modernitesinin birçok referans fikrini yıkan Taha Abdurrahman'ın kitaplarında ${ }^{13}$ Batılı ve

\footnotetext{
${ }^{6}$ Piotr Sztompka, The Sociology of Social Change, Blackwell, Oxford 1993, s. 69-85.

${ }^{7}$ Gurminder K. Bhambra, Rethinking Modernity: Postcolonialism and the Sociological Imagination, Palgrave Macmillan, Basingstoke 2009, s. 11.

${ }^{8}$ Anthony Giddens, The Consequences of Modernity, Polit, Cambridge 1990, s. 149.

${ }^{9}$ Jean-François Lyotard, The Postmodern Condition: A Report on Knowledge, Translated by Geoffrey Bennington and Brian Massumi and foreword by Fredric Jameson, University of Minnesota Press, Minneapolis 1984.

${ }^{10}$ S. N. Eisenstadt, Comparative Civilizations and Multiple Modernities, Brill, Leiden 2003.

${ }^{11}$ Peter Wagner, Modernity as Experience and Interpretation: A New Sociology of Modernity, Polity Press, Cambridge 2008, s. 12 .

${ }^{12}$ Robert W. Hefner, Civil Islam Muslims and Democratization in Indonesia, Princeton University Press, Princeton 2000.

${ }^{13}$ Taha Abdurrahman, Rûhu'l-Hadâse: el-Medhal ilâ Te'sîsi' 'l-Hadâseti'l-İslamiyye, el-Merkezu's-Sekâfiyyi'l-Arabî, Beyrut 2006.
} 
İslamî moderniteler arasında köklü bir fark olduğu görülmektedir, dolayısıyla İslamî modernitenin tanımı bu sorunlu alandan çıkarılamaz.

"Sağlam" bir modernite kavramının olmamasıyla ilgili bu sorunsaldan yola çıkarak, modernist veya İslamî olanın mahiyetiyle ilgili ayrımlar ve hükümler sorununu aşacağım. Başka bir deyişle bu makalenin amacı, modernist değerlerin makâsıd kavramlarına ne ölçüde nüfuz ettiğini araştırmak değildir. Çünkü bu, modernist ile modernist olmayan, batılı modernite ile evrensel modernite veya İslamî modernite ile İslamî olmayan modernite ile ilgili önceki sorunun çözülmesini gerektirir. Ancak burada moderniteden belirli bir fikirler bütünü olarak değil bir sistem olarak bahsediyorum, ${ }^{14}$ aynı şey sistematik bir yapı olarak İslam hukuku bahislerimiz için de geçerlidir. Buradaki sistematik yapı ile, sadece bir hükümler bütünü olmanın ötesine geçen kurumlar, değerler, hükümler, ictihad mekanizması ve bunun olaylara nasıl tatbik edildiğine dayanan mütekamil bir İslam hukuk sistemini kastediyorum. ${ }^{15}$

\section{Yenilenme ve Süreklilik Arasında Makâsıd}

Mütekaddimîn dönemi fakihleri zarurî maksatları dinin, canın, aklın, neslin ve malın korunması olarak beşe ayırmıştır. ${ }^{16} \mathrm{Bu}$ ayrım şöhret bulmuş ve el-ïhkâm'ında ${ }^{17}$ Âmidî (ö. 1233), el-Muhtasar' 'nda ${ }^{18}$ İbnü'l-Hâcib (ö. 1249) gibi bir çok alim tarafindan zikredilmiştir. Bunun yanında Zerkeşî (ö. 1392) farklı bir sıralamayla bu maksatlardan bahseder ${ }^{19}$ ve Şâtıbî de aklı sona bırakarak "derler ki; bu değerler her millette esas alınmıştır." ${ }^{20}$ ifadesini kullanır. Şâtıbî, makâsıdı genişletmiş, kamilen bir kitabını, el-Muvâfakât'ını tahsis ederek bu konuyla ilgilenmiş ve detaylandırarak geliştirmiş̧ir.

Bununla birlikte Şâtıbî’nin makâsıd alanına katkısı birçok yoruma konu olmuştur. Örneğin Muhammed Âbid el-Câbirî (ö. 2010), "Şafî̀'den Gazâlî̀ye usûl düşüncesi lafizlardan manaları çıkarmaya çalışıyordu. Şâtıbî geldiğinde Arap beyanî düşüncesinde muazzam bir epistemolojik dönüşüm başladl." ${ }^{21}$ demektedir. Mu'tez el-Hatib, Câbirî’nin bu sözleriyle ilgili tartışmaya katılarak Şâtıb̂̀’nin ifadelerine onun kastetmediği modern manaların nasıl yüklendiğini izah etmiştir. Benim de katıldığım bu izaha göre, açıkça görünüyor ki Şâtıbî -önemli bir yenilik getirdiğini kabul etsek de- köklü bir değişimi veya geçmişten kopuşu temsil etmemektedir. ${ }^{22}$ Zira Şâtıbî, kitabına "el-Muvâfakât" ismini vermiştir, çünkü İbnu'l-Kâsım ile Ebû Hanîfe'nin

\footnotetext{
${ }^{14}$ Bir sistem olarak modernitenin anlamı, daha sonra bu modernist sistemin bir özelliği olarak akışkanlıktan bahsetmeye başladığımızda ortaya çıkacaktır.

15 Bkz. Wael Hallaq, "Can Shari'a be Restored", in Islamic Law and the Challenges of Modernity, edited by Yvonne Haddad and Barbara Stowasser, Altamira Press, Walnut Creek 2004.; Anver Emon, "Shari'a and the Modern State." In Islamic Law and International Human Rights Law: Searching for Common Ground? edited by Anver Emon, Mark S. Ellis, and Benjamin Glahn, Oxford University Press, Oxford 2012; Mu'tez el-Hatib, elFakih ve'd Devle: Mu'daletu'l-Fakih fî Zilli's-Sevrâti'l-Arabiyye, Tebeyyün, 2013, 9, 63-84.

${ }^{16}$ Ebu Hâmid el-Gazâli, el-Mustasfâ, el-Mektebetu'l-Vakfiyye, Kahire 2010, s. 322.

${ }^{17}$ Ebu Huseyn Âmidî, el-İhkâm fí Usûli'l-Ahkâm, el-Mektebetu'l-İslamî, Beyrut t.y., c. 3, s. 274.

${ }^{18}$ Ebu Amr İbnu'l-Hacib, Muhtasaru Müntehe's-sûl ve'l-Emel fî 'İlmeyi'l-Usûl ve'l-Cedel, fî: Şemseddin Isfahanî, Beyanu'l-Muhtasar Serhu Muhtasar İbnu'l-Hacib, Daru'l-Medeni, Riyad 1986, c. 3, s. 114.

${ }^{19}$ Muhammed bin Abdullah Zerkeşî, el-Bahru'l-Muhît fì Usûli'l-Fikh, Daru'l-Kütübî, Kahire 1994, c. 7, s. 266.

${ }^{20}$ Ebu İshak eş-Şâtıbî, el-Muvâfakât fì Usûli'ş-Şerîa, el-Mektebetu'l-Asriyye, Beyrut 2002, c. 2, s. 8. [çev. Mehmet Erdoğan, İz Yay., İstanbul 2016; alıntılarda bu çeviriden yararlanılmıştır çev. not.].

${ }^{21}$ Muhammed. Ẩbid Câbirî, Bunyetu'l-Akli'l-Arabî, Merakizu Dirasâti'l-Vahdeti'l-Arabiyye, Beyrut 2009, s. 547.

22 Mu'tez el-Hatib, el-Makâsid ve İlmu'l-Usûl: Kıraatun fî Nusuki'l-Ma'rifî, fî'r-Rabitati'l-Alemiyyeti'lMuhammediyye, Makâsıdu'ş-Şerî'ati ve's-Siyaku'l-Kevniyyi'l-Muasır, Rabat 2013, s. 41-58.
} 
görüşlerini uzlaştırmayı murad etmişti. ${ }^{23}$ Bu uzlaştırma, ihtilaflar için hakim bir merci oluşturmak şeklinde bir tecdid teşebbüsü olsa bile önceki mirasa karşı bir isyan ve devrim ifade etmiyordu. Zaten esasında Şâtıbî ve İbnu'l-Kâsım, Mâlik'in (ö. 795) mezhebine sıkı sıkıya bağlı fakihlerdi. Mesela Şâtıbî’yi, “el-Í ‘tisâm” kitabının mukaddimesinde şunu söylerken buluruz: “Bana atfedilen, daha doğrusu iftira edilen şekilde mükellefiyet ve fetvalar hususunda müntesibi olunan mezhebin meşhur görüşünün gereklerini aşmam söz konusu değildir, buna tevessül edenler fetva isteyenlerin kolaylı̆̆ını düşünerek hevalarına göre fetva vermiş olurlar, mezhepte -hakim görüş olsun ya da olmasın- şazz olarak yer alsa bile ilim sahibi olan imamlarımız buna karşı çıkmaktadırlar."24 Meşhur olan mezhebin aşılabileceğini kabul etmeyen birinin usûl sistematiğinde tamamen bir devrim yapması tasavvur edilemez. Bunun delili, onun kendisi hakkındaki söyledikleri değildir, getirdiği şeyin gelenekten sapma değil, daha ziyade kendisinden önceki alimlerin yolu üzere olduğunu şu ifadeleri tekid eder: "Ĕger bu kitaptan kabul etmeyeceğin yerler olursa, sezgi ve anlama kapıları kapalı kalırsa ve 'bu duyulmadık bir şey, mahiyet ve işleniş bakımından ne şer'i temel ilimlerde ne de fer'i ilimlerde böyle bir eser telif edilmemiştir, onun ortaya konulması ve yayılması kötülük ve bidat olarak yeterlidir' şeklinde bir zan belirirse, sakın denemeden, tecrübe etmeden mesele çıkarıp da dikkate alıp faydalanma imkanını ortadan kaldırıp atma. Çünkü bu kitap Allah'a hamdederek belirteyim ki, ayet ve hadislerin ortaya koyduğu şeylerdir, onun temellerini selef-i salihîn atmış, özelliklerini derin alimler belirlemiş, rükünlerini düşünürler sağlamlaştırmışlardır." 25 Onun "özellikleri alimler tarafindan belirlenmiş" ifadesi, kendisini seleflerinin çabalarının bir devamı olarak gördüğüne delalet eder. F1kıh usûlüne yönelik eleştirilerine gelince, aslında durum sanıldığı gibi değildir; Şâtıbî’nin çağrısı, fikıh usûlünü amele terettüp etmeyen meselelerden korumaya yöneliktir ve bu da usûl metodunun eleştirilmesi veya yeni ve farklı bir usûl tesis edilmesi demek değildir. ${ }^{26}$ Zaten bu eleştiriyi getiren ilk fakih Şâtıbî değildi, ondan önce Gazâlî (ö. 1111) el-Mustasfâ kitabında usûlcülerin amele yansımayan konulara yoğunlaşmalarını ve usûl ile kelamın karışmasını eleştirmişti. ${ }^{27} \mathrm{Bu}$ da ilave veya yenilemeyi ortadan kaldırmasa da, usûl geleneğinden soyutlanma ve onu değiştirme manasına gelmemekteydi.

Eğer Şâtıbî'nin durumu buysa, benim yeni makâsıd hareketi olarak isimlendirdiğim şey nedir? Bu hareketin ortaya çıkışı başından beri modernite ile irtibatlıydı; Tunuslu Hayreddin, Akvâmu'l-Mesâlik'inde, Gazâlî ve İbnu'l-Kayyım'ın (ö. 1350) konuyla ilgili sözlerini iktibas ederek makâsıdı, Osmanlı hilafetindeki siyaseti, batıda mevcut olan sisteme benzer bir hale getirerek 1slah etmenin aracı olarak görmüştür. ${ }^{28}$ Sonra Muhammed Abduh, Tunus ziyareti sırasında el-Muvâfakât ile tanışmış ve kitaptan etkilenmiş, Mısır'a döndügünde talebelerini ve sevenlerini bu kitabı okumaya ve neşretmeye teşvik etmiştir. Abduh, makâsıdı ıslah projesi için kolay bir araç olarak görmüştür. ${ }^{29}$ Daha sonra talebesi Reşid Rıza (ö. 1935) da aynı amaçla

\footnotetext{
23 Şâtıbî, c. 1, s. 12.

${ }^{24}$ Ebu İshak Şâtıbî, el-I'tisam, Mektebetu’t-Tevhid, t.y., s. 21.

25 Şâtıbî, c. 1, s. 14.

26 Şâtıbî, c. 1, s. 22.

27 Gazâlî, s. 15 .

${ }^{28}$ Ridvan Seyyid, Makâsıdu'ş-Şerî‘a fî̀ Kitâbâti'l-Arabi'l-Muhaddisîn ve Muasırîn, fî A 'mali Nedve Tatavvuru'lUlûmi'l-Fıkhiyye: el-Makâsıdu'ş-Şerî'a, Vizârâtu'l-Evkaf ve'ş-Şuûnu'd-Diniyye, Umman 2012.

${ }^{29}$ Muhammed Hudarî, Usûlü'l-Fıkh, el-Mektebetü't-Ticâriyyetü'l-Kübrâ, Kahire 1969, s. 13; Abdullah Draz, Talikât fî Hamişi 'l-Muvâfakât, telif: Ebu İshak Şâtıbî, Kahire, s. 12.
} 
Cemaleddin Kâsımî'nin (ö. 1914) ilgili risalesini Menar Dergisi'nde neşretmesinin akabinde Necmeddin Tûfî' den (ö. 1316) maslahat görüşünü almıştır. Bu görüş, Wael Hallaq'ın birçok Arap ülkesinin batılılaşmasını sağladığı veya teşvik ettiği şeklinde tanımladığı bir görüştür. ${ }^{30}$ Makâsıda itimad etme fikri, 1970lere kadar Mısır ve Tunus'taki müelliflerin kitaplarında dolaşmaktaydı. Bilahare makâsıd çalışmalarında benzeri görülmemiş bir patlama yaşanmıştır. Öyle ki İslam dünyasındaki düşünce tarihini araştıran herhangi bir talebe, "İslamî uyanış" olarak bilinen şeyi ve bunun makâsıd fikrinin yaygınlığı ile olan ilişkisini ihmal edemez. O dönemde güçlü bir şekilde yeniden alevlenen İslamî proje, İslam ile moderniteyi, başta modern devlet olmak üzere çeşitli kurumlarıyla uyumlu bir hale getirme imkanına dayanmaktaydı. Bu fikir, bir kısıtlamayı temsil eden nassı, dışındaki vakıayla uyumlu hale getirme imkanı için bir arayışı gerekli kılmaktaydı. Nassın sınırlılığından ve zahirinden bir sapma olarak anlaşılan makâsıd, bu arayışta önemli bir rol oynamıştır. Yani Hallaq'ın dediği gibi makâsıd, seküler bir çözümden kaçınmanın ve aynı zamanda nassın çerçevesi dışına çıkmanın bir yolu olarak şekillenmiştir. ${ }^{31}$ Ancak makâsıdın kendisine yüklenen bu rolü ${ }^{32}$ oynayabilmesi için üzerinde birtakım değişiklikler yapmak gerekmekteydi. Moderniteye ve değişimlerine ayak uydurmanın bir aracı olmanın kapısını açacak genişleme ve gelişme olmadan onu en iyi şekilde kullanmak mümkün olmazdı.

\section{Yeni Makâsıd Ekolü ve Çağdaş Dönüşümler}

Yeni makâsıd ekolünün söylemlerinde, geleneksel makâsıd çalışmalarından uzaklaşmayı gösteren iki bariz dönüşüm gözlemlenebilir: Birincisi, beş maksadın uygulama kapsamını genişletmek; ikincisi ise, bunları makâsıdın içine modern kavramları yerleştirmek için arttırmak ve değiştirmektir.

\section{A. Şeriatı/İslam Hukukunu Rasyonelleştirme}

Makâsıd, ta'lil (illetlendirme) meselesiyle bağlantılıdır; yani şer‘̂̂ hükümlerin illetinin tespiti konusuna dayanmaktadır, Şâtıbî’nin ta 'lilin kelamî boyutundan bahsetmeyi kasıtlı olarak atlamasına rağmen, ta'lil bir tartışma konusuydu ve hâlâ da öyledir. Bazıları makâsıd fikrinin, Allah'ın fiillerinin bir illete dayandırılmasını reddeden Eş‘arî mezhebinden saptığını düşünürken, ${ }^{33}$ diğerleri kelamcıların reddettiği gâî illete dayandırma ile fakihlerin ortaya koyduğu makâsıd ile ta'lil arasında bir fark olduğu fikrindedirler. İlkinin fiil ile olan ilişkisi zorunlu bir ilişkidir, çünkü buradaki ilişki, fiili yaratma sebebidir, sebepsiz hiçbir fiil olmadığı fikrini kelamcılar reddeder, çünkü bir şeyin Allah için vacib/zorunlu olması sonucuna götürür. İkincisi ise Allah'ın kullarına bir lütfudur, illet hükmün temel amacı değildir. ${ }^{34}$ Buradaki illet, hükmün temeli olmayıp daha çok sonradan kurulmuş bir ilişki olduğu için fakihlerin bazı hükümlerin taabbüdî olmasına itirazları yoktur. Bu nedenle onların şer'î hükümleri, manası akılla kavranabilen hükümler ve -taabbüdî olarak isimlendirilen- manası akılla kavranamayan hükümler şeklinde taksim ettiklerini görürüz. İbnu'l-Arabî (ö. 1148) şöyle der: “Kıyasın kapsamı ibâdâtla ilgili

\footnotetext{
${ }^{30}$ Wael Hallaq, "Maqāṣid and the Challenges of Modernity." Al-jāmi a' 49 (1): 1-32, 2011, s. 11.

${ }^{31}$ Hallaq, s. 12.

${ }^{32}$ Bkz. Mu 'tez el-Hatib, el-Vazifetu'l-Makâsıdiyyu: Meşruiyyetuhâ ve Ğâyâtuha, İslamiyyetu'l-Ma 'rife, 2007, 48, 943.

${ }^{33}$ Ahmed Tayyib, Nazariyyetu'l-Makâsıd 'inde'ş-Şâtıbî ve medâ İrtibatuha bi'l-Usûli'l-Kelamiyye, el-Müslimu'lMuasir, 2002, s. 103.

${ }^{34}$ Ahmed Raysuni, Nazariyyetu 'l-Makâsıd 'inde 'l-İmam Şâtıbî, el-Ma ‘hedü'l-Alemî li'l-Fikri'l-İ̀slâmî, Virginia 1995, s. 207-254.
} 
hükümler bakımından dardır, ibadetler doğrudan nasslara dayanmaktadır, kıyasın yapılacağı kisım muamelâttrr." ${ }^{35}$ Yine İbn Dakîkul'îd (ö. 1302) de "ibâdât ve buna dair hükümler ancak tevkîf [Şâri 'in bildirmesi] ile alınır" ${ }^{\prime 36}$ demektedir.

Fakihler taabbüdün yorumlanmasında ihtilaf etmişlerdir. Bazıları, taabbüdden muradın, Allah'ın emirlerine kullarının itaatlerini imtihan etmek olduğu için, asıl itibariyle illetten yoksun bulunduklarını ifade etmişlerdir. Bu bağlamda Şâtıbî şöyle der: "Taabbüdî konularda istenilen şey, sadece emre uymak ve ne eksik ne de fazla, olduğu gibi o şeyi yerine getirmektir. Bunun içindir ki Hz. Aişe'ye (r.anhâ) birisi: 'hayızlı kadın, niçin orucunu kaza ediyor da namazını kaza etmiyor?' diye sorduğunda, ona 'sen Harûra meşrepli misin?' demiş̧ ve bu tip soruların sorulmasına karşı tepkisini belirtmiştir. [Zira taabbüdî konular, özel illeti anlaşılsın diye konulmuşşeyler değildir. Sonra Hz. Aişe (r.anhâ) 'biz orucu kaza etmekle emrolunurduk; namazı kaza etmekle emrolunmazdlk' demiştir. Onun bu sözü, konunun taabbüdi oluşunun meşakkatle ta 'lilî yönüne gidilmesinden daha isabetli olacağını göstermektedir.] Şâri 'in, parmakların diyetini eşit kllması konusu ile ilgili olmak üzere, İbnu'l-Müseyyeb'in: 'yeğenim, sünnet bu şekilde' diye karşllı vermesi de bu kabîldendir. [Örnekleri çoğaltmak mümkündür. Bundan da anlaşıllyyor ki,] taabbüdî konularda illet bulunmamaktadır." ${ }^{37}$ Gazâlî, şeriatın saf taabbüdî hükümlerinin amacının kulların akıl sır erdiremedikleri bir fiili yaparak teslimiyetlerini göstermeleri için bir imtihan olduğunu söyler. ${ }^{38}$ Ancak Karâfî (ö. 1285), ibâdâta dair hükümlerin de hikmetli olduğunu, fakat bizim bunlara vakıf olamadığımızı, bu nedenle haklarında bilgi sahibi olmamamızın ibâdâta ilişkin hükümlerin hikmetten yoksun oldukları anlamına gelmediğini ve Allah'ın fiillerinin tamamının hikmetli olduğunu söyleyerek başka bir tavır alır. Mesela o, namaz vakitlerinin illetlendirilmesi hususunu açıklarken şöyle der: "bizim bilmediğimiz hikmetler içerirler ve bu nedenle ibâdât kapsamında yer alırlar." ${ }^{39}$ Başka bir meselede de "aynı şekilde ibâdâta dair meselelerin bizim bilmediğimiz manaları ve hikmetleri vardır, bunları bilmememiz manasız ve hikmetsiz olduklarl anlamına gelmez" ${ }^{\prime 40}$ demektedir. Lakin açıkladığımız iki görüşün şu şekilde cem‘ edilmesi mümkündür; Şâtıbî, Allah'ın fiillerinin hikmetli olduğuna itiraz etmez, ancak o, başka bir yerde bahsettiği gibi, hikmeti daha ziyade Allah'a bağlılık, emirlerine teslimiyet, yalnızca O'na karşı saygı duymak, O'nu yüceltmek ve O'na yönelmek olarak değerlendirir. ${ }^{41}$ Aynı şekilde Karâfi, Allah'ın irade buyurduğu hikmetin bilgisinin araştırılmasına karşı çıkmaz. Her ikisi de nerede olursa olsun şer'î hükümleri savunur ve onu ihlal edecek yorumlardan kaçınırlar, zira bu hükümler taabbüdî niteliktedirler ki bu da gayr-1 makul (akılla tam olarak açıklanamayan) lafzını kullandığımız durumdur. Bu, bazı hükümlerin kıyas veya makâsıd veyahut başka bir yolla diğer hükümlere geçiş yapmadıklarının kabul edilmesidir, burada zahiri itibariyle emre boyun eğme kastıyla yapılan ibadetle ilgili meseleler söz konusudur.

Öte yandan, yeni makâsıd hareketi, şeriatı ve hükümlerini rasyonelleştirilmek amacıyla fikıhtaki saf taabbüdî yönü azaltmak veya ortadan kaldırmak için çalışmışır. Şer‘î hükümlerin

\footnotetext{
${ }^{35}$ Ebubekir İbnu'l-Arabî, el-Mahsul, Daru'l-Beyarık, Umman 1999, c. 1, s. 95.

36 İbn Dakiku'l‘îd, İhkâmu'l-Ahkâm Şerhu Umdeti'l-Hükkam, Matbaatu's-Sunneti'l-Muhammediyye, t.y., c. 1, s. 203.

37 Şâtıbî, c. 2, s. 292.

${ }^{38}$ Ebu Hâmid Gazâlî, İhyau Ulûmi'd-Din, Daru'l-Marife, Beyrut 2004, c. 1, s. 212.

${ }^{39}$ Şihabuddin Karâfi, el-Furûk, Alemu'l-Kütüb, Beyrut, t.y., c. 2, s. 57.

${ }^{40}$ Karâfî, c. 2, s. 141.

${ }^{41}$ Şâtıbî, c. 2, s. 230.
} 
rasyonelleştirilmesine yönelik genişlemenin erken bir dönemde başladığı ifade edilebilir. Örneğin İbn Âşûr'u, Şâtıbî'nin taabbüd ile ilgili sözlerine itiraz ederken buluruz. Bu bağlamda o şöyle der: "Şâtıb̂̂, taabbüd ve ta 'lil hakkında çoğu karışık ve düzensiz uzun bir açıklama yapmıştır." İ́smail Hasenî de şunu ifade eder: "Makâsıd düşüncesinin çıkış noktası ta'lildir, çünkü hükümlerinin rasyonelleştirilmesine izin vermeyen herhangi bir hukuk sistemi, zamanların ve çağların dönüşümlerini kuşatmaya müsait değildir." ${ }^{43}$ Vasfi Aşur, şer'î hükümlerin, bazılarının bildiği ve diğer bazılarının da bilmediği yüce hikmetler ve anlamlar için vaz' edildiği görüşündedir, bazılarının -özellikle ibâdât hükümlerinin illetleri- meçhul olması bunların bilinemeyeceği anlamına gelmez, bilakis bu hikmetlere vâkıf olmak için araştırma yapılmasının gerekliliğine işaret eder. $^{44}$ Başka bir deyişle Vasfi Aşur'a göre sorun, bazı müctehidlerin bu hikmetleri idrak edememesidir, daha fazlası değil.

Bu anlam, konuya epistemolojik ve varoluşsal bir boyut kazandıran Taha Cabir Alvânî’nin eserlerinde daha açıktır. Burada mesele, kul ile Tanrı arasındaki ilişkinin tabiatı ve kulluk ve boyun eğme kavramlarıyla alakalı hale gelir. Ona göre tüm hükümlerin manaları akılla kavranabilir, bununla beraber bir müctehid diğerine göre daha kavrayışlı, bir nesil illetleri idrak etmede diğerine göre daha vukuf sahibi, bir ülkenin insanları bu hususta diğerlerine göre daha zeki olabilir. Taabbüd mefhumu söylemleri arasında yer alan mestler üzerine mesh vermenin taabbüdî nitelikte olduğu ve makul bir manasının bulunmadığı hususu fakihlerin hatalarından biridir ve taklidin yayılması için hazırlanan ve Allah'ın hükümlerinin yine onun bildirdiği delil ile değiştirilmesine yardımcı olan hastalıklı fenomenlerden biridir. Ancak Alvânî, 'ubudiyet' kelimesinin -bu manasıyla- illet ve maksadını anlamadan efendisine her konuda itaat etmesi gereken kölenin durumu ile arasında bir ayniyet olduğu görüşündedir. Bunun nedeni, itaatin mutlak olması ve fiilin anlamını veya maksadını kendisine sormaya izin vermemesidir. 'Abd' sözcügüne gelince Allah Teala'ya nispetle kullanıldığında körü körüne boyun eğme ve aşağılama değil, kula şeref ve değer katan ifadelerden biridir. Şeref ve değer katmak için uygun olan fiiller, manası akılla kavranabilen kalp ve bedenin yapması gereken görevlerdir. İnsanın Allah'a kulluğu onu özgürleştirir, kurtuluşa ve yükselişe götürür. Bununla beraber Alvânî, fakihlerin saf taabbüdî meselelerle ilgili sözlerinin diğer dinlerden etkilendiği görüşündedir. İslam'a gelince o, tüm insanların zincirlerini kırmaya ve kaldırmaya gelmiştir. İslam, Yahudilerin tasavvurunda olduğu gibi ordu kumandanının emirlerini yerine getirmekten başka seçenekleri olmayan askerlere veya kölelere verilen emirlerden müteşekkil bir hukuk sistemi değildir. ${ }^{45}$

Ta ‘lilin bu geniş anlamı Câsir Avde'nin el-Fetavâu'l-Makâsıdî diye isimlendirdiği şeyde uygulama alanı bulur. O, Müslüman olmuş bir kadının kafir kocasının yanında kalmasıyla ilgili hükümde şöyle der: "Bir kadının kocası olmadan Müslüman olması durumundaki maksatlara gelince, (ülkenin dâru'l-harb veya dâru'l-İslam olmasına bakılmaksızın) Hudeybiye Anlaşması'ndan sonra nazil olan Mümtehane ayetinin nüzul sebebini düşünürsek mümin kadınları

\footnotetext{
42 Tâhir bin Âşûr, Makâsıdu'ş-Şerî‘ 'ati'l-İslamiyye, Daru's-Selam, Kahire 2005, s. 45.

${ }^{43}$ İsmail Hasenî, Nazariyyetu'l-Makâsıd 'inde'l-İmam Tâhir bin Âşûr, el-Ma 'hedü'l-Alemî li' l-Fikri'l-İslâmî, Virginia 1995, s. 23.

${ }^{44}$ Vasfi Aşur, Ahkâmu'ş-Şerî‘ati beyne’t-Taabbüd ve’t-Ta'lil, fî I'mali'l-Makâsıd beyne't-Teheyyüb ve't-Teseyyüb: Mecmuatu Buhûs, Tahrir: Ahmed Raysuni, Müessesetu'l-Furkan li’t-Turasi'l-İslamiyyi, London 2014.

${ }^{45}$ Taha Cabir Alvânî, Mukaddime: Hasenî, İsmail, Nazariyyetu'l-Makâsıd 'inde'l-İmam Tâhir bin Âşûr, el-Ma'hedü’lAlemî li' l-Fikri'l-İslâmî, Virginia 1995, s. 7-15.
} 
kafir kocalarına iade etmemedeki maksadın müslüman kadınların dinini korumak olduğunu görürüz. Bu kapsamda onların dinlerinden dönmeye zorlanmalarl veya müslümanlıkları sebebiyle zarar görmelerini engelleme amacı gözetilmiştir. Her ne kadar dikkat edilecek şey, sebebin hususiliği değil, -kelimenin genel anlamıyla, lafzın umumiliği olsa da sebep, lafzın medlullerini, umum ve hususunu anlamamızı sağlayan şeydir. Buna göre ĕger yeni müslüman olan kadın, kocası tarafindan eziyet gördü ve zarara uğradiysa şüphesiz ayrlmalart için desteklenmelidir, ancak adam ahlaklı ise durum farklıdır." 46 Burada eşlerin ayrılığı aklî bir meseledir ve illetiyle beraber değerlendirilir. İlk bakışta bu hüküm taabbüdî olarak görülebilir. Bu yüzden mesela fakihler, kadınların iddet süresinin hikmeti, hamile olmadıklarının açı̆̆a çıkması iken hamilelik durumunun olmadığı bilimsel analizler ve modern cihazlarla tespit edilmiş olsa bile, iddet süresi boyunca kadınların evlenmesine izin vermezler, çünkü burada aslolan taabbüdîliktir, taakkul (akıl yürütme) ile hükme varılamaz. Şâtıbî şöyle der: "Biz, nikahta istenilen veli, mehir gibi şartların nikahın zinadan ayrılması için arandı̆̆ını, mirasta belirlenen payların, varislerin ölüye olan yakınlı̆̆ına göre olduğunu, iddet ve istibradan gözetilen amacın, neseblerin birbirine karışmasını önlemek olduğunu kavrayabiliyoruz; ancak bunlar genel boyutlu manalardır. Nitekim bu manada ibadetlerden gözetilen maksadın da Allah'a tazimde bulunmak, O’na karşı huşu duymak ve saygı göstermek olduğunu kavrayabiliyoruz. Ancak bu kadarı, (genel hatlarlyla kavranılabilen bu hikmetleri) üzerine başkalarını kıyas edebileceğimiz bir asıl kılabilecek güçte değildir. Dolayısıyla, ĕger nikahın zinadan ayrılması, nikahta aranan şartların dışında başka yollarla da gerçekleşiyorsa, o zaman illa da ileri sürülen şartların gerçekleşmesi aranmaz; rahmin temiz olduğu herhangi bir yolla sabit olursa kur' ya da ay hesabı ile iddet beklemesinin bir anlamı kalmaz, şeklinde yorumlara gitmek doğru olmayacaktır." 47 Udeh'e gelince o, manay rasyonelleştirmiş ve sonra bunu illetin mecrasına çevirmiştir.

Sosyologlar, dinin -tarihsel olarak- müminlerine bu dünyada felah ve ahirette kurtuluş vaat eden bir sığınak olduğunu söylerler. Dolayısıyla hükümleri de bu iki boyuta dayalı olarak oluşmuştur, bu boyutlar bir hükümde birleşebilir veya ayrılabilir. Ancak her şeyi rasyonelleştirme konusundaki modernist ısrar, bu tekliflerin, emir ve yasakların dayandığı illetleri anlama çabasını gerekli kılmıştır. Hükme mutlak olarak boyun eğme fikri bazılarınca artık rasyonelleştirme eğiliminin yaygın olduğu bir bağlamda kabul edilebilir değildir. Trafik 1şıklarında rasyonel olarak neden durulacağını anlayan bir insan, dini de rasyonel olarak anlamaya ihtiyaç duymaktadır. ${ }^{48} \mathrm{Bu}$ nedenle metafizik ve eskatolojik açıklamalar modernist kişilikte artık pek yer almamaktadır. Abdulkader Tayob şöyle der: "Modern öncesi dönemde dinlerin hedefi ahirette kurtuluştu, modern çă̆a gelince dinin topluma somut bir yararı olmadı̆̆ tasavvur edilmez, bununla beraber dinin yeni biçiminde Tanrı'nın üstünlüğ̈̈ fikrinin getirdiği veya getirmeyi taahhüt ettiği sosyal fayda aracılığıyla gerekçelendirilmesi gerekmektedir, dolayısıla bu fayda da tartışmalara ve sert münakaşalara konu olmuştur."49 Taabbüd kavramı, geçmişte insanları ibadetleri yerine getirmeye teşvik etmek için yeterliydi, ancak bugünün insanı ibadetin toplumu ve hayatı için öneminin rasyonel ispatına ihtiyaç duymaktadır.

\footnotetext{
${ }^{46}$ Casir Avde, el-İctihadu'l-Makâsıdiyyu min Tasavvuri'l-Usûliyyi ile't-Tenzili'l-Ameliyyi, eş-Şebeketu'l-Arabiyyi li'l-Ebhas ve'n-Neşr, Beyrut 2013, s. 110.

47 Şâtıbî, c. 2, s. 525.

${ }^{48}$ Bryan R. Wilson, Religion in Sociological Perspective, Oxford University Press, Oxford 1982, s. 43-45.

${ }^{49}$ Abdulkader Tayob, Religion in Modern Islamic Discourse, Columbia University Press, New York 2009, s. 68-70.
} 
Bu mana, yeni makâsıd ekolünün makâsıdu'ş-şerî‘anın uygulanmasını genişlettiklerinde ortaya çıkan dönüşümü anlamanın mümkün olduğu çerçeveyi oluşturur. Bu nedenle onlar öncelikle- şeriatın taabbüdî alanını kaldırmaya veya azaltmaya çalışmışlardır. Böylece tüm hükümler, modern insanın aklının alabileceği açık ve mantıklı illetlere dayandırılabilecektir. Yine bu şekilde ilahi emir; anlayış, açıklama veya gerekçe olmaksızın tek başına mutlak itaati gerektirmez ve bu hükümler de -ikinci olarak- varlık ya da yokluk illetleri üzerine bina edilmiştir. Yorum sadece hükümlerin hikmetlerini anlamak ve şeriatın güzelliğini idrak etmek açısından ${ }^{50}$ değil aynı zamanda hükümleri bu illetler üzerine kurmak için de önemlidir. Rasyonelleştirme ve makâsıd arasındaki ilişki, bu bağlamda birbirini gerektiren bir ilişkidir. Şeriattaki rasyonel alanı ne kadar genişletirsek zorunlu olarak makâsıdı uygulayabileceğimiz alan da o kadar genişler ve makâsıdı önceki makâsıd alimleri tarafından bahsedilmeyen alanlarda ve sahalarda kullanabiliriz.

\section{B. Makâsıdı Yeniden Belirlemek ve Tanımlamak}

Yeni makâsıd ekolü için yapılması gereken iş, sadece ta'lilin, taabbüdî hükümler alanını azaltma veya kaldırma noktasına kadar genişletilmesi değildi, bununla beraber makâsıdın anlamlarını ve sayılarını yeniden tanımlamaydı; buna karşın mütekaddimîn dönemi alimleri beş temel maksadı takip ediyordu, bunlar; dini, nefsi, aklı, nesli ve malı korumaktı. Bu korumanın amacına dair verilen örnekler de birbirine yakındır; dini korumanın mahiyetine örnek olarak mürtedin öldürülmesi, nefsi korumaya örnek olarak kısasın vacib oluşu, aklı korumaya örnek olarak içki içme cezası, nesli koruma için ise zina edenin recm edilmesi ve malın korunması için de hırsızın elinin kesilmesi gibi. Şâtıbî bu bağlamda şunu söyler: "Íbadetlerle beşeri davranışlara (âdât) misal verilmiştir. Muamelât ise, insanın başkasıyla birlikte olan ve bir maslahatın teminine yönelik davranışlarıdır. (...) Cezâ̂ hükümler (cinâyât) ise, korunması istenilen şeyleri ortadan kaldırmaya yönelik fiillerdir. Bu duruma engel olacak ve söz konusu maslahatların ortadan kalkması durumunda onların telafisine yönelik önlemler alınmış ve gerekli hükümler getirilmiştir. Nefsin korunması için getirilen kısas ve diyet hükümleri, aklın korunması için getirilen had cezası, neslin korunması için malların kıymetlerinin tazmini, malın korunması için el kesme ve tazminat hükümlerinin getirilmesi bu kabîlden olmaktadır. Zarûriyyâtın tamamı beş konuda toplanır: dinin, nefsin, aklın, neslin ve malın korunması."51 Ancak yeni makâsıd ekolü, iki dönüşüm ihdas etmiştir,

\footnotetext{
50 Bazıları meseleyi bu şekilde çözmüştür, ibadetlerle ilgili şüpheli bir hikmetten bahsetmenin, bugün bizim gerçekliğimiz olması sebebiyle fikhi ta'lil için kullanılan makâsıdın bir parçası olduğu düşünülüyor ki bu doğru değildir. [Hakim] et-Tirmizi der ki: “Tekbirin illetine gelince insan sadece içinde bulunduğu kibir nedeniyle O’na itaatsizlik eder, oysa ki O’na bir söz vermiş ve demiştir ki: Allahu Ekber!” (Muhammed Abdu, Ta'lilu'ş-Şerî‘a beyne't-Teseyyüb ve't-Tesahul, fî I'mali'l-Makâsıd beyne't-Teheyyüb ve't-Teseyyüb: Mecmuatu Buhûs, Tahrir: Ahmed Raysuni, Müessesetu'l-Furkan li’t-Turasi'l-İslami, London 2014, s. 312.) Bunun zahiren makâsıd ictihadıyla hiçbir alakası yoktur ve burada makâsıd hakkında konuştuğumuzda kelimelerin değil fikirlerin tarihinden bahsediyoruz. Örneğin İbnu'l-Kayyım, ibadetle ilgili hükümlerin hikmetleriyle fazlaca meşgul olmuştur; teyemmümün iki uzuvla sinırlandırılması, hacamatla orucun bozulması ve yellenmeyle abdestin bozulmasını illetleriyle açıklamıştır. (Raysuni, s. 191.) Fakat amacı bundan yola çıkarak bahsettiği illetlerden fikhi hükümler inşa etmek değil, ictihadlarından anlaşıldığına göre Yüce Allah'ın hükümlerindeki hikmetlerin güzellik ve nezaketine vakıf olmaktı ve -elbette- bu da zanni bir akıl yürütmeydi. Ta'lili, hikemî ve istidlalî olmak üzere iki kısma ayırmamız mümkündür. İlki, oruç nefse boyun eğdirmek için, hac Allah'ın şeâirini tazim için, kefaret günahları affettirmek için, zekat cimrilik kötülüğünden korunmak için konulmuş olmaları gibi ilmin nüktelerindendir. (İsmail Nukaz, Felsefetu'tTa 'lil fî Fikri'l-İmameyn eş-Şâtıbî ve'd-Dihlevî, Mu'minune Bila Hudud, 2016; Veliyyullah Dihlevî, Huccetullahi'lBaliğa, Daru'l Cîl, Beyrut 2005, s. 27-28.) Bunlara fikhi amel bina edilmiyor, şeriatın güzelliği ve hikmetlerini gösterme amacı güdülüyor ki bu hususta herhangi bir tartışma yoktur. Ama sorun ta'lil yoluyla istidlal açısındandır, bu durumda taabbudi hüküm ta'lil edilir ve sonra tespit edilen illetten başka bir hükme varılır.

${ }^{51}$ Şâtıbî, c. 2, s. 20.
} 
bunların ilki; bu beş maksat ile neyin kastedildiğinin yeniden yorumlanması, ikincisi ise; bu beşine yenilerinin eklenmesi veya muhtevalarında değişiklik yapılmasıdır.

Açıktır ki, mürtedleri öldürme, zina edeni taşlama, hırsızı had ile cezalandırma ve katile kısas fikri; çevresindeki hukukî, insanî ve şer‘î tartışmalardan uzak birçok çağdaş için artık İslam anlayışının merkezinde yer almamaktadır. Bu nedenle, makâsıd ekolü, özellikle de İslam dinini, modern vakıayla uzlaştırmaya çalışan bir reform projesinde kullanmak istediklerinde makâsıdı yeniden yorumlamaya ihtiyaç duymaya başlamışlardır. Örneğin Şatibî’de dinin korunmasını gözetmek, müşriklerle savaşmak ve İslam'ın izzetini savunmak anlamına gelir ve Allah'ın dinini kurcalamaya kapının açılmaması için mürtedleri öldürmek demektir. Gannuşî’ye göre de, hürriyet maksadından yola çıkarak Müslümanların Müslüman olmayanlar arasında dinlerini anlatmalarına izin verildiği gibi, Müslüman olmayanların da Müslümanlar arasında dinlerini tebliğ etmelerine müsaade edilmesi gerekir. ${ }^{52}$ Aklı korumak; sarhoş edici maddelerden uzak durmak ve onu içenleri cezalandırmaksa, o zaman Karadavî'ye göre aynı zamanda bilgi arayışını teşvik etmek, gençleri ilme yönlendirmek, taklitçiliğe yöneldikleri zaman onları bundan uzak tutmak anlamına da gelir. ${ }^{53}$ Aklı koruma kavramının bu tanımına ve bu kavramın ümmetin ilerlemesinin bilimsel çerçevede dönüşümüne dayanarak Karadavî, aklın korunması amacıyla -örneğin ilim öğrenmek için- bazı Avrupa ülkelerindeki Müslüman kızların, okula girerken çıkarmaya zorlanmaları halinde, başörtülerini çıkarmalarına cevaz vermiş ve okula gidilmesine vesile olmuştur. ${ }^{54}$ Mütekaddimîn dönemi alimleri için malın korunması, onu savunmak ve hırsızın elini kesmek anlamına geliyorsa da Umer Chapra, koruma fikrinin anlamsız olduğuna ve onu başarı veya gelişme fikriyle değiştirmemiz gerektiğine inanır. ${ }^{55}$ Câsir Avde'nin -daha açık bir şekilde- pazara hakim olan büyüme ve ilerleme kavramını tersine çevirmek amacıyla ekonomik kalkınma yoluyla malın korunmasını $^{56}$ açıkladığında ifade ettiği şey de bunu destekler.

Yeni makâsıd ekolü, makâsıdı yeniden tanımlamanın yanı sıra, bilinen beşine yenilerini ekledi; çünkü artık bu maksatlarla sınırlı kalması mümkün değildi. Örneğin Karadavî’yi özgürlük, kardeşlik, eşitlik, dayanışma ve insan hakları gibi ilkelerin getirilmesi çağrısını yaparken buluyoruz. ${ }^{57}$ Cemaleddin Atıyye maksatların sayısını katlayarak yirmi dörde çıkardı. ${ }^{58}$ Haşim Kemali ise şeriatın maksatlarının sınırlı olduğunu iddia etmenin mümkün olmadığına inanmakta ve bu maksatlara dünya barışı, ekonomik ilerleme, bilimsel araştırma ve anayasal haklar gibi amaçlar eklemektedir. ${ }^{59}$ Tarık Ramazan da bunlara; haysiyet, refah, bilim, yaratıcılık, bağımsızlık, kalkınma, eşitlik, özgürlük, adalet, kardeşlik, sevgi, dayanışma ve çeşitliliği koruma ve geliştirme

\footnotetext{
${ }^{52}$ Andrew March, "The Maqșad of Hifẓ al-Dīn: Is Liberal Religious Freedom Sufficient for the Sharî‘ ah?” Islam and Civilizational Renewal, vol. 2, no. 2, 358-378, 2011, s. 365.

53 Yusuf Karadavî, Dirasetun fì Fikhi Makâsıdl'ş-Şerî'ati beyne'l-Makâsıdı'l-Külliyeti ve'n-Nususi'l-Cüz'iyye, Daru'ş-Şurûk, Kahire 2008, s. 30.

${ }^{54}$ Yusuf Karadavî, Hilkatu Meftûhatun li'l-Alameti'l-Karadavî, Bernamec: "eş-Şerî‘'atu ve'l-Hayat" 'alâ Kanati'lCezire, www.aljazeera.net/programs/religionandlife/2010/11/3/يوسفالقرضاوي-للعلامة_مفتوحة_حلقة: E.T: 01.11.2017).

${ }^{55}$ Umar Chapra, The Islamic Vision of Development in the Light of Maqāsid Al-Sharī'a, Islamic Research and Training Institute, Islamic Development Bank, Jeddah 2008, s. 8.

${ }^{56}$ Avde, s. 22.

${ }^{57}$ Karadavî, s. 28.

${ }^{58}$ Cemaleddin Atıyye, Nahve Tef'ili Makâsıdi'ş-ŞSî̀'a, el-Ma'hedü'l-Alemî li’l-Fikri'l-İslâmî ve Dımeşk, Daru'lFikr, Virginia 2001, s. 139.

${ }^{59}$ Mohammad Hashim Kamali, "Māqāṣid or Sharī'ah," Ijtihad and Civilizational Renewal, IIIT, Washington and London 2012.
} 
gibi amaçlar ve başkalarıyla insan ilişkisine dair amaçların yanında sağlık, zeka, üreme, çalışma, aidiyet ve komşuluk gibi ilkeler de eklemiştir. Toplumla ilgili maksatlar ise şunlardır; hukukun üstünlügünü ve bağımsızlığı, danışmayı, çoğulculuğu, gelişimi, kültürleri, dinleri ve mirası korumak ve geliştirmek. ${ }^{60}$

Bununla birlikte yeni makâsıd hareketi, maksatlarda nicelik ve nitelik olarak bir değişiklik meydana getirmiş ve modernist değerler ışığında dinin merkezini, amaçlarını ve gereklerini yeniden tanımlamada önemli bir değişiklik üzerinde çalışmıştır. Abdulkader Tayob bu anlamda şöyle demektedir: "Modernite, İslam'a büyük bir meydan okuma oluşturdu ve modernistler, mevcut değişikliklerle başa çıkmak için İslam metodolojisini yeniden tanımlamaya başvurdular. Bu çalışma geleneksel veya muhafazakar bakış açısıyla tutarl görünmeyebilir, ancak İslam metodolojisini sabit değerler olarak görmekten uzak bir şekilde, İslam'in modernitenin meydan okumalarına tepkisini ifade etmektedir." ${ }^{\prime \prime}$ Dinin gerileme veya ilerlemesi fikrinden sarf-1 nazar ederek modernitenin din üzerindeki etkisini anlamak mümkündür. Modernitenin din üzerindeki etkisi, ilk dönem sosyologların iddia ettiğinin aksine, dinin kamusal alandan kaybolmasına sebep olup, sürecin sonunda dinin tamamen gerilemesi ve yok olmasi sonucunu doğuran, sekülerleşmeden kaynaklanan, devamlı bir fiiliyatın ortaya çıkması değildir. Bu durum, modernitenin dini etkilemediği ve dinin, eleştirmenlerin söylediği gibi dünyanın çeşitli yerlerinde hala güçlü ve baskın olduğu anlamına gelmez, aksine modernite dini, ilke ve değerleri ile uyumlu bir formda yeniden tezahür ettirmeye çalışmıştır. ${ }^{62}$

Buradaki amacımız, bu değişikliğin meşru bir değişiklik olup olmadığı hakkında hüküm vermek değildir. Bu durum da, hem din hem de modernitede neyin sabit ve neyin değişken olduğunun belirlenmesine bağlıdır. Bu, yukarıda bahsedilen ilkelerin her birinin ayrıntılı bir incelemesini gerektirir ve bu çalışma, makâsıdı vakıanın gerektirdiği şekilde genişletmenin meşruiyetini inkar etmez, ayrıca önceki alimlerin ictihatları üzerinde durulmasını da gerektirmez, daha ziyade -daha geniş bir perspektiften- bu değişimin bir bütün olarak İslam hukuku üzerindeki etkisini değerlendirmeye çalışır. Makâsıdın tanımı hususundaki bu değişiklik, dinin temel maksatlarının sabit bir şey olmadığının, aksine mekansal ve zamansal değişimlere göre değişebileceğinin kabul edilmesi anlamına gelir. Böylelikle şeriatın temel maksatları, evrenselcilikten zamansal ve mekansal göreceliliğe geçmektedir. Modernitenin makâsıd üzerindeki etkisi sadece makâsıdu'ş-şerî‘a ile modernite kavramları arasındaki uyum değildir. Daha derin bir perspektiften bakıldığında, hukukçular ve düşünürler için mesele, fikrî, ideolojik, zamansal ve mekansal göreceliliğe bağlı olarak bu makâsıdı akışkan moderniteye adapte etmektir. $\mathrm{Bu}$ görecelilikten doğan sonuçların batı değerlerine yakın veya uzak olması bu bağlamda önem arz etmez.

Buradaki mesele, Hallaq'ın da eleştirdiği gibi makâsıdın modern devlet ve siyasetin hegemonyasından kaçamayacağı veya yetkilerini aşamayacağı sorunu değildir. Makâsıdın devletin değerlerini belirlemede şekillendirilebilir bir araç olabileceği doğrudur. Bu durum

\footnotetext{
${ }^{60}$ Tariq Ramadan, Radical Reform: Islamic Ethics and Liberation, Oxford University Press, New York 2009, s. 140143.

61 Tayob, s. 46.

${ }^{62}$ Germán McKenzie, Interpreting Charles Taylor's Social Theory on Religion and Secularization: A Comparative Study, Springer International Publishing, Vancouver BC 2017, c. 1, s. 26.
} 
Muhammed Ebu Rida (ö. 1991) nazarında apaçık ortadadır. Ebu Rida, makâsıdu'ş-şerî‘aya, halihazırdaki önemine binaen -dinin, nefsin, aklın, neslin ve malın korunması maksatlarına ek olarak- devletin korunması şeklinde altıncı bir maksadın eklenmesi gerektiği görüşündedir. ${ }^{63}$ Ancak diğer taraftan, örneğin Muhammed Gazâlî’nin (ö. 1996) ifade özgürlüğü, siyasi özgürlük, yöneticileri seçme ve onları şeriatın maksatlarına göre değiştirme hakkıyla birlikte, ayrıca devleti yöneten otoritelerin yetkilerini sınırlandırmak için makâsıdı kullanmaya çalıştığını görüyoruz. Cemaleddin Atıyye, [Ebu Hâmid] Gazâlî’ den gelen klasik yaklaşımı, onun zulüm ve adaletsizlikle dolu bir hayat sürmüş olmasına bağlamaktadır. Atıyye'nin şeriatın maksatlarından biri olarak hürriyet kavramını öne çıkarması da bu nedenledir. ${ }^{64}$ Aynı zamanda makâsıd hareketi, reform, modernizasyon $^{65}$ veya içtihatların serbestleştirilmesi ${ }^{66}$ arayışına indirgenemez. Gannuşî’nin dini koruma şemsiyesi altında din özgürlüğü çağrılarının aksine, dinin korunması Seyyid Kutub (ö. 1966) tarafından farklı bir perspektiften anlaşılmıştır. Kutub için bir din vaz' etmek, insanlığı, insan(lar)a köle olmaktan Rabbe kul olmaya yükselterek özgürleştirmek demektir. Din, "başlangıçta insanoğlunun egemenliğini ve insandan insana esarete dayanan sistemleri ve hükümetleri ortadan kaldırmayı amaçlamaktadır. Ancak bundan sonra, yani siyasi baskı üzerlerinden kaldırlldıktan sonra bireyler aslında kendi tercihleriyle istedikleri inancı seçmeleri için serbest kalmış olacaklardır." ${ }^{67}$ Cihadın talep edilmesi dinin korunmasıyla yakın ilişkisi nedeniyle meşru bir hale gelmiştir, fakat bu, Gannuşî’nin bakış açısının tam tersidir. Hallaq bu konuda şunları ifade eder: "Reşid Rıza'nın maslahat fikri, birçok Arap ülkesinin kanunlarının batılılaşmasına yardımcı olmuştur."68 Yine Sherman Jackson'1n, İslam dininin, aklı, batı hegemonyasından kurtarması ve Amerika' daki siyahîlere uygulanan ırkçılık hakkında konuşurken aklın korunması maksadını kullandığını görüyoruz. ${ }^{69}$ Heba Rauf ise şöyle demektedir: "Şûrâ bir fitrat, ictimaî bir sünnet ve İslam şeriatının maksatlarına ulaşmak için bir araçtır. Dolayısıyla kadınların siyasi hayata entegrasyonları yoluyla şûrâ meclislerine katılmaları İslam'ın şer 'î maksatlarına ulaşmanın araçlarından biridir."70 Diğer tarafta ise Haşim Kemali’nin, zamana ve ilgiye ihtiyacı olan çocuğun beklediği annelik görevini alt üst eden, evden ayrılan kadın konusunda değerlerdeki dengesizliği eleştirirken, bu durumun fitrat ile çeliştiğini ve fitratın da makâsıda ulaştıran kaynaklardan temel bir kaynak olduğunu ifade ettiğini görüyoruz ve o, "bu şeriatın maksatlarına aykırıdır" demektedir. ${ }^{71}$

Önceki yorumlara katılıp katılmamak bir tarafa, söylemeye çalıştığım şey, yeni makâsıd hareketindeki temel sorunun evrenselcilikten akışkan bir göreceliliğe geçiş olduğudur. Bu, dini dış faktörlerden güçlü bir şekilde etkilenmeye karşı savunmasız hale getirebilir ve modernist

\footnotetext{
${ }^{63}$ Atiyye, s. 99.

${ }^{64}$ At1yye, s. 98

${ }^{65}$ Adis Duderija, "Contemporary Muslim Reformist Thought and Maqāșid cum Mașlaḥa Approaches to Islamic Law: An Introduction." In Maqāșid al-Sharī $a$ and Contemporary Reformist Muslim Thought: An Examination, edited by Adis Duderija, Palgrave Macmillan, New York 2014.

${ }^{66}$ March, s. 370.

${ }^{67}$ Seyyid Kutub, Fî Zilâli’l-Kur'an, Daru'ş Şuruk, Kahire 1991, c. 3, s. 1435.

${ }^{68}$ Hallaq, s. 11.

${ }^{69}$ Sherman Jackson, “Literalism, Empiricism, and Induction: Apprehending and Concretizing Islamic Law’s Māqāṣid or Sharī'ah in the Modern World”, Michigan Law Review, 1469-1486, 2006, s. 1484.

${ }^{70}$ Heba Rauf İzzet, el-Mir'atu ve'l-Amelu's-Siyasiyyu: Ru'yetu İslamiyye, el-Ma'hedü'l-Alemî li'l-Fikri'l-İslâmî, Virginia 1995, s. 142-149.

${ }^{71}$ Kamali, s. 26-27.
} 
kavramları pekiştirmek veya tam tersi, isteyenlerin elinde dini şekillendirmek için bir araç haline gelebilir. Sorun, mevcut makâsıdın yukarıdaki farklılıkların tümü için fikhî/hukukî gerekçelendirme kabiliyetinde yatmaktadır. Katı ve kapalı formundan akışkan forma geçişte, İslam hukukçuları için makâsıdda dış etkilerin karıştırılmasına ve katı dini kalıbın özünün değişmesine yol açan bir kapı vardır. Zygmunt Bauman (ö. 2017) bu bağlamda şunu ifade etmiştir: "Modernite, eski katı kalıpları yenileriyle değiştirmeden ortadan kaldırmaya geldi, heyhat ki ancak bir sabite -bu da akışkanlık ve değişimdir- kaldı, bu nedenle mesele, bireysel kimlikleri gönüllü olarak seçme özgürlügüne bırakılmıştır ve artık herkesin izlemesi gereken yekpare bir yaklaşım yoktur."72 Lassander'in, post-seküler dini, akışkan bir din olarak kavrayışında bu akışkanlık, onun yarı ilahî ve yarı insanî olmasından kaynaklanır. Dolayısıyla, post-seküler din, iki boyuttan birini temsil etmesi açısından indirgenemez ve onu seküler ve dinî gibi olağan bölümlere ayırma teşebbüsü mümkün görülmemektir. ${ }^{73}$ Bu nedenle, -cüz'î nasslardan fikhî hükümler çıkaran metodolojiden daha geniş bir metodolojiye izin veren yeni biçimiyle- makâsıda başvurmak, daha fazla esneklik sağlayan ve cüz'î kıyasın sınırlamalarını aşan daha geniş bir kabiliyet temin etmiştir. Ancak bu genişleme aynı zamanda İslam hukukçusunu çevreleyen gerçeklik üzerinde daha büyük bir etkiye kapı açmaktadır. Şâtıbî’nin geçmişte şu sözleriyle uyardığı, bu göreceliliktir: "Makâsıd, nisbîlik ve izafilik özellikleri gösterdiğinden maslahatlar, mükelleflerin algısı açısından değil, yalnızca şeriatın statüsü açısından değerlendirilir." ${ }^{74} \mathrm{Bu}$, Bakıllâni’yi (ö. 1013), maslahatlara yönelik önyargılı yapan korkunun aynısıdır. O şöyle demektedir: “Bu kapıyı (maslahat) açmanın hiçbir temeli yoktur ve bu, ehl-i nazarın [filozoflarin] peygamberler (aleyhimüsselam) konumuna yükselmesine yol açar, halbuki onların görüşleri şeriata nispet edilemez ve bu görüşler, şeriatın ihtişamın geçersiz kılmak ve herkesin kendi görüşleriyle hareket etmesi için bir bahanedir. Öyleyse bu, zamana, mekana ve yaratma türlerine göre değişir, bu nedenle filozofların anlayışı geçersizdir." 75

Görünüşe göre makâsıd ekolünden bazıları, hükümlerini dayandırdıkları maksatların göreceliliğini ilan etmekte bir beis görmemişlerdir, moderniteden etkilenmek veya etkilenmemek hakkında konuşmak yerine, insanın başlangıçta toplumundan ve zamanından uzak küresel fikirler geliştiremeyeceğini görmekteler. Câsir Avde diyor ki: "Müctehid bir ilim adamı, şer '̂̀ nassları okurken, Şâri Teala’nın kastettiği belirli bir niyeti istikrâ yoluyla keşfederek, zihnindeki tasavvurlarının şer'î nasslar ile çağdaşlarının dünya görüşü arasındaki etkileşimini bu maksatla ifade eder." "76 Burada bir şeyi şer‘̂̂ olarak hüsün (iyi) ve kubuh (kötü) olarak değerlendirme ile dünya görüşünün insan ürünü olması arasında bir çelişki görmez. Tarık Ramazan'a gelince o, Allah'ın bize iki kitap indirdiğine inanır; bunların ilki Kur'an ve ikincisi evrendir. Şer'î hükme erişim de ancak bu iki kitap arasındaki etkileşimle mümkündür. ${ }^{77} \mathrm{Bu}$, tıpkı Taha Cabir Alvânî’nin makâsıdın iki kıraattan yani nass ve evrenin okunmasından çıkarılması gerektiğini savunmasına benzemektedir. ${ }^{78}$ Bazı araştırmacılar bu ekolü ilkinden farklı bir ekol olarak sınıflandırmakta;

\footnotetext{
${ }^{72}$ Zygmunt Bauman, Liquid Modernity, Polity Press, Cambridge 2006, s. 6-7.

${ }^{73}$ Mika Lassander, "Grappling with Liquid Modernity: Investigating Post-secular Religion”, in Post-secular Society, edited by Peter Nynas, Mika Lassander, and Terhi Utriainen, Routledge, London and New York 2017.

74 Şâtıbî, c. 2, s. 29.

75 Abdullah İbn Bayyah, Alâkatu Makâsıdi'ş-Şerî'ati bi-Usûli’l-Fıkh, Müessesetu'l-Furkan, London 2006 , s. 46.

${ }^{76}$ Avde, s. 15.

${ }^{77}$ Ramadan, s. 128.

78 Alvânî, s. 5.
} 
ilkini modernist ve bu ikincisini post-modern ekol olarak değerlendirmektedirler. ${ }^{79}$ Lakin bana öyle geliyor ki iki taraf arasında pek fazla fark yoktur; her ikisi de modernist görecelilikten etkilenmiştir, her ikisi için de makâsıd kendi gerçekliklerinin ve görüşlerinin bir yansıması haline gelmiştir; ancak tek fark, iki ekolden birinin bu etkiyi teorik boyuta aktarmada daha açık olmasıdır. Her iki ekol de temellerinin şeriata dayandığı gibi vakıaya da dayandığını söyler. Post-modern ekol olarak ele alınan diğerleri her ne kadar açıkça itiraf etmeseler ve bu etkiyi teorik bir söyleme taşımasalar da bu modernist görecelilikten etkilenmekten rahatsız değildirler.

Şeriatı anlamaya yönelik herhangi bir girişimin, bir kişinin yaşadığı gerçeklikten etkilenebileceği bir sır değildir. Bu etki sadece yeni makâsıd ekolü için değil, aynı zamanda Gazâlî, Karâfi, Şâtıbî ve diğerlerinin kitaplarındaki geleneksel makâsıd anlayışı için de geçerlidir. Ancak modern ve modern öncesi gerçekliğin insanların üzerindeki etkisinin karşılaştırılması, haksız bir karşılaştırma olur. Yeni makâsıd ekolünde olduğu gibi, erken dönem makâsıd alimlerinin de kendi gerçekliğinden etkilendiği iddiası, birbirine benzemeyen şeyler arasında yapılan bir kıyastır ki bunun da birkaç nedeni vardır:

Birincisi; modernitenin her yere ulaşma yeteneği emsalsizdir ve modernite -Anthony Giddens'in dediği gibi- "özünde küreselleşmiştir." 80 Modernite, çok fazla teknoloji veya gelişme elde edemeyen alanlarda bile dünyanın her yerine nüfuz etmiştir. Dünyanın içinde yaşadığı siyasi sistem, modern devlete bağımlılığı ve ulusçuluk fikrine dayanması açısından modernist bir sistemdir. Kabile, grup ve geniş aile gibi bir dereceye kadar ayrılık ve farklılığa sahip olan eski oluşumların aksine ekonomik düzeyde kapitalizm; işbölümleriyle, ulusötesi ve dev kurumlarıyla, sermayeye dayalı sistemi ve bankacılık kurumlarıyla egemen hale gelmiştir. Teknolojiden ve onun her yere nüfuz etme kabiliyetinden bahsetmiyorum bile. Bütün bunlar modernitenin yayılmasına yardımcı olmuştur. Bu, -sırasıyla- bireysellik, değişim, görecelilik, rasyonalizasyon, sekülerleşme, işlevsel parçalanma ve İslam'ın hemfikir olabileceği veya katılmayacağı diğer modernist fikirler gibi unsurları taşıyan bir gemiydi. Eski zamanlarda olduğu gibi modernleşme akımlarına direnebilecek veya reddedebilecek izole adalar artık yoktur.

İkincisi; makâsıdın uygulama alanlarının genişletilmesidir. Daha önce de belirtildiği gibi rasyonelleştirme alanındaki genişleme ve başka nedenlerle eski makâsıd alanı, günümüzün makâsıd alanı ile karşılaştırılamaz. Makâsıdın kullanılması çeşitli fikıh ve fıkıh dışı alanlarda artmıştır. Bu genişlemenin bir sonucu olarak da, makâsıdın savunmasızlığı da giderek artmıştır. Yeni makâsıd ekolü artık birçok şeyi makâsıd perspektifinden değerlendirebilir. Örneğin, Haşim Kemali'ye yapılan bir eleştiri, çocukları erken yaşta okula getirmenin şeriatın maksatlarına aykırı olduğu inancına dayanmaktaydı. Çünkü fitrat, açıkça çocukların bu yaşta oyun oynama ve çocukluklarının tadını çıkarma hakları olduğunu söyler. Fıtrat da, makâsıdın kaynaklarından biri olduğu için, çocukları küçük yaşta okula getirmek makâsıda uygun olmaz. ${ }^{81}$ Makâsıdın mevcut vakıada uygulanması ile karşılaştırıldığında, bu oldukça spesifik nitelikteki izdüşümler, ciddi şekilde sınırlı olan eski makâsıd teorisinde bulunmamaktaydı.

79 David Johnston, "Maqasid or Shari'a: Epistemology and Hermeneutics of Muslim Theologies of Human Rights", Die Welt des Islams 47 (2): 149-187, 2007, s. 149.

${ }^{80}$ Giddens, s. 63.

${ }^{81}$ Kamali, s. 27. 
Üçüncüsü ise; cüz'î maksatlara veya nasslara güvenmekten daha çok şeriatın küllî maksatlarına itimad etmektir. Bu da önceki alimlerin tasarruflarından farklıdır. Bunun nedeni, şeriatın genel ilkelerinin bu geniş yorumbilimsel imkanları ile karşılaştırıldığında nassa dayanan akıl yürütmenin, sınırlı bir nitelikte olan lafızların yorumlama kapasitesine bağlı kalmasıdır. $\mathrm{Bu}$ bağlamda özellikle de cüz’i makâsıdın fikhın cüz’î meseleleriyle sınırlı kalmasına yönelik ${ }^{82}$, yeni makâsıd ekolüne açık bir çağrı söz konusudur. ${ }^{83}$

\section{SONUÇ}

Bu makale, yeni makâsıd ekolünün, makâsıdu'ş-şer̂‘‘adan farklı, yeni bir makâsıd söylemi oluşturma çabasını tartışmaktadır. Bu söylem, büyük ölçüde eski makâsıd geleneğine dayanmasına rağmen, makâsıd çalışmasındaki en son paradigma kayması iki konuda tezahür etmektedir: Birincisi; muamelât veya ibâdât olsun, tüm şer'î ahkâmın rasyonelleştirilmesine vurgu yaparak makâsıdın uygulanmasını genişletmek ve şeriata mutlak boyun eğme ve tam itaat kavramlarının dışından bakmaktır. İkincisi ise; makâsıd kavramının nicelik ve nitelik açısından genişletilmesidir. Nicelik açısından makâsıd, beş veya altı maksat ile sınırlandırılmamış, bu sayı bazı İslam hukukçuları için daha fazla, bazıları için ise sayısız hale gelmiştir. Nitelik açısından ise mevcut beş maksat yeni içerik ve boyutlar kazanmıştır.

Bu değişim İslam hukuk sistemini sıkıntıya sokmuş; yeni makâsıd ictihadı, ictihad alanındaki hususlarda beşerî alanı genişletmiş̧ir. Bu, makâsıd şemsiyesi aracılığıyla birçok farklılı̆̆ı ve ayrılığı haklı çıkarmak için yapılan ictihad geçerli hale getirilene kadar, makâsıdı çeşitli görüşlere dini meşruiyet kazandırmak için bir araç haline getirmiştir. Böylelikle makâsıd, hükümlerin hikmetlerini öğrenme vesilesi iken çeşitli durumlara uyum sağlama konusundaki büyük yeteneği ve farklı görüşleri telif imkanı nedeniyle, Müslüman bir düşünür ya da hukukçunun içinde yaşadığı vakıadan kaynaklanan önyargılı görüş ve fikirleri meşrulaştırmakta kullandığı bir araca dönüşmüştür. $\mathrm{Bu}$, çeşitli hukuk sistemlerinde yüksek ilkelerin tabiatında var olan bir şeydir. Bir İslam hukukçusunun makâsıdı, fetvalarında veya entelektüel çalışmalarında -olumsuz ya da olumlu- nasıl kullanacağını öğrenmek için, onun devlet, feminizm ya da batı hakkındaki konumunun bilinmesi yeterlidir. Modernitenin makâsıd çalışmaları üzerindeki etkisi, sadece şer‘̂̂ maksatların modern ilkelere yakınlaşması ya da tam tersi uzaklaşması değildir. Bunun ötesinde esas etki, modernist sistemin önemli bir özelliğinin (akışkanlığının) makâsıda kazandırılmasıdır. Makâsıd1, -bu görecelilik ister modern değerlere yaklaşmakla sonuçlansın ister tam tersi olsunİslam hukukçularının ve düşünürlerin entelektüel, ideolojik, mekansal veya zamansal göreceliliğine rehin bırakan şey budur. İctihaddaki bu akışkanlık, -ki o içinde yaşadığımız modern sürecin bir yansımasıdır- esnek bir yön olarak da görülebilir. Ama aynı zamanda bu akışkanlık, başka bir bakış açısından- ortaya çıkan meselelerde veya ihtilaflarda şeriatın muayyen hükmünü belirlemekte acze düşüldüğü için, İslam hukukunun toplumsal kontrolü sağlama yeteneğini azaltabilir veya tamamen atıl birakabilir.

\footnotetext{
82 Alvânî, s. 6.

${ }^{83}$ Kamali, s. 3.
} 


\section{KAYNAKÇA*}

Abdu, Muhammed, Ta'lilu'ş-Șerî‘a beyne't-Teseyyüb ve't-Tesahül, fî̀ I'mali'l-Makâsıd beyne'tTeheyyüb ve't-Teseyyüb: Mecmuatu Buhûs, Tahrir: Ahmed Raysuni, Müessesetu'l-Furkan li't-Turasi'1İslamî, London 2014.

Abdurrahman, Taha, Ruhu'l-Hadase: el-Medhal ilâ Tesisi'l-Hadaseti'l-İslamiyye, el-Merkezu's Sikafiyyu'l Arabî, Beyrut 2006.

Alvânî, Taha Cabir, Mukaddime: Hasenî, İsmail, Nazariyyetu'l-Makâsıd 'inde'l-İmam Tâhir bin Âşûr, el-Ma'hedü'l-Alemî li’l-Fikri'l-İ̀slâmî, Virginia 1995.

Âmidî, Ebu Huseyn, el-íhkam fí Usûli'l-Ahkâm, el-Mektebetu'l-İslamî, Beyrut t.y.

Așur, Vasfi, Ahkâmu'ş-Șerî‘ati beyne't-Taabbüd ve't-Ta'lil, fî I' mali'l-Makâsıd beyne't-Teheyyüb ve't-Teseyyüb: Mecmuatu Buhûs, Tahrir: Ahmed Raysuni, Müessesetu'l-Furkan li't-Turasi'l-İslamiyyi, London 2014.

Atıyye, Cemaleddin, Nahve Tef'ili Makâsıdi'ş-Şerî'a, el-Ma'hedü'l-Alemî li'l-Fikri'l-İslâmî ve Dımeşk, Daru'l-Fikr, Virginia 2001.

Avde, Câsir, el-İctihadu'l-Makâsıdiyyu min Tasavvuri'l-Usûliyyi ile't-Tenzili'l-Ameliyyi, eşŞebeketu'l-Arabiyye li'l-Ebhas ve'n-Neşr, Beyrut 2013.

Bauman, Zygmunt, Liquid Modernity, Polity Press, Cambridge 2006. [Akışkan Modernite, çev. Sinan Okan Çavuş, Can Yay., İstanbul 2017].

Bhambra, Gurminder K., Rethinking Modernity: Postcolonialism and the Sociological Imagination, Palgrave Macmillan, Basingstoke 2009. [Moderniteyi Yeniden Düşünmek: Post-Kolonyalizm ve Sosyolojik Tahayyül, çev. Özlem İlyas, İstanbul Bilgi Üniversitesi Yay., İstanbul 2015].

Bûtî, Muhammed Said, Nahve Tecdidi Usûli'l-Fıkh, fî İskaliyyeti Tecdidi Usûli'l-Fıkıh, Daru'l Fikr, Dımeşk 2006.

Cabirî, Muhammed Abid, Bunyetu'l-Akli'l-Arabî, Merakizu Dirasâti'l-Vahdeti'l-Arabiyye, Beyrut 2009. [Arap Aklının Yapısı, çev. Burhan Köroğlu \& Hasan Hacak, Mana Yay., İstanbul 2020].

Chapra, Umar, The Islamic Vision of Development in the Light of Maqāṣid Al-Sharī'a, Islamic Research and Training Institute, Islamic Development Bank, Jeddah 2008.

Dihlevî, Veliyyullah, Huccetullahi'l-Baliğa, Daru'l Cîl, Beyrut 2005. [çev. Mehmet Erdoğan, İz Yay., İstanbul 2020].

Draz, Abdullah, Talikât fì Hamişi'l-Muvâfakât, telif: Ebu İshak Şâtıbî, Kahire.

Duderija, Adis, "Contemporary Muslim Reformist Thought and Maqāṣid cum Mașlaḥa Approaches to Islamic Law: An Introduction." In Maqāșid al-Sharī 'a and Contemporary Reformist Muslim Thought: An Examination, edited by Adis Duderija, Palgrave Macmillan, New York 2014.

Eisenstadt, S. N., Comparative Civilizations and Multiple Modernities, Brill, Leiden 2003.

Emon, Anver, "Shari'a and the Modern State." In Islamic Law and International Human Rights Law: Searching for Common Ground? edited by Anver Emon, Mark S. Ellis, and Benjamin Glahn, Oxford University Press, Oxford 2012.

Gazâlî, Ebu Hâmid, el-Mustasfa, el-Mektebetu'l-Vakfiyye, Kahire 2010. [çev. Hacı Yunus Apaydın, Klasik Yay., İstanbul 2018].

Gazâlî, Ebu Hâmid, Ihyau Ulûmi'd-Din, Daru'l-Marife, Beyrut 2004. [çev. Mustafa Çağrıc1, Diyanet İşleri Başkanlığı, Ankara 2020].

\footnotetext{
* Türkçe çevirisi olan kaynaklar köşeli parantez içinde belirtilmiştir. [çev. not.]
} 
Giddens, Anthony, The Consequences of Modernity, Polit, Cambridge 1990. [Modernliğin Sonuçları, çev. Ersin Kuşdil, Ayrıntı Yay., İstanbul 2016].

Hallaq, Wael, "Can Shari'a be Restored", in Islamic Law and the Challenges of Modernity, edited by Yvonne Haddad and Barbara Stowasser, Altamira Press, Walnut Creek 2004.

Hallaq, Wael, "Maqāṣid and the Challenges of Modernity." Al-jāmi 'ah 49 (1): 1-32, 2011.

Hasenî, İsmail, Nazariyyetu'l-Makâsıd 'inde'l-İmam Tâhir bin Âşûr, el-Ma'hedü'l-Alemî-li'lFikri'l-İslâmî, Virginia 1995.

Hatib, Mu'tez, el-Fakih ve'd-Devle: Mu'daletu'l-Fakih fî̀ Z1lli't-Sevrâti'l-Arabiyye, Tebeyyün, 2013, 9, 63-84.

Hatib, Mu'tez, el-Makâsıd ve İlmu'l-Usûl: Kıraatu fî Nusuki'l-Ma'rifî, fî'r-Rabitati'l-Alemiyyeti'lMuhammediyye, Makâsıdu'ş-Şerî'ati ve's-Siyaku'l-Kevniyyi'l-Muasır, Rabat 2013, 41-58.

Hatib, Mu'tez, el-Vazifetu'l-Makâsıdiyyu: Meşruiyyetuhâ ve Ğâyâtuha, İslamiyyetu'l-Ma 'rife, 2007, 48, 9-43.

Hefner, Robert W., Civil Islam Muslims and Democratization in Indonesia, Princeton University Press, Princeton 2000.

Hudarî, Muhammed, Usûlü 'l-Flkh, el-Mektebetü’t Ticâriyyetü'l Kübrâ, Kahire 1969.

İbn Âşûr, Tâhir, Makâsıdu'ş-Şerî‘ati'l-İslamiyye, Daru's-Selam, Kahire 2005. [İslam Hukuk Felsefesi, çev. Vecdi Akyüz \& Mehmet Erdoğan, Rağbet Yay., İstanbul 2013]. 2006.

İbn Bayyah, Abdullah, Alakatu Makâsıdi'ş-Şerî'ati bi-Usûli'l-Fıkh, Müessesetu'l-Furkan, London

İbn Dakiku'l'îd, İhkamu'l-Ahkâm Şerhu Umdeti'l-Hükkam, Matbaatu's-Sunneti'l-Muhammediyye, t.y.

İbnu'l-Arabî, Ebubekir, el-Mahsul, Daru'l Beyarık, Umman 1999.

İbnu'l-Hacib, Ebu Amr, Muhtasaru Muntehe's-sûl ve'l-Emel fî İlmeyi'l-Usûl ve'l-Cedel, fî: Şemseddin Isfahanî, Beyanu'l-Muhtasar Şerhu Muhtasar İbnu'l-Hacib, Daru'l Medeni, Riyad 1986.

İmam, Muhammed Kemaleddin, ed-Delilu’l İrşadi ilâ Makâsıdi'ş-Şerî‘a, Daru’l Furkan, London 2008-2012.

İzzet, Heba Rauf, el-Mir'atu ve'l-Amelu's-Siyasiyyu: Ru'yetu İslamiyye, el-Ma'hedü'l-Alemî li'lFikri'l-İslâmî, Virginia 1995.

Jackson, Sherman, "Literalism, Empiricism, and Induction: Apprehending and Concretizing Islamic Law's Māqāṣid or Sharī'ah in the Modern World", Michigan Law Review, 1469-1486, 2006.

Johnston, David, "Māqāṣid or Sharī'a: Epistemology and Hermeneutics of Muslim Theologies of Human Rights", Die Welt des Islams 47 (2): 149-187, 2007.

Kamali, Mohammad Hashim, "Māqāṣid or Shan̄'ah," Ijtihad and Civilizational Renewal, IIIT, Washington and London 2012.

Karâfi, Şihabuddin, el-Furûk, Alemu'l Kütüb, Beyrut, t.y.

Karadavî, Yusuf, Dirasetun fî Fılkhi Makâsıdı'ş-Şerî'ati beyne'l-Makâsıdı 'l-Külliyeti ve'n-Nususi'l Cüz'iyye, Daru'ş-Şurûk, Kahire 2008.

Karadavî, Yusuf, Hilkatu Meftûhatun li'l-Alameti'l-Karadavî, Bernamec: "eş-Şerî'atu ve'l-Hayat" 'âla Kanati'l-Cezire, $\quad$ www.aljazeera.net/programs/religionandlife/2010/11/3/للعلامة_مفتوحة_حلقة' (E.T: 01.11.2017). 
Kars, Aydoğan, "Māqāṣid or Sharī'a? Secularism, Islamic Reform, and Ethics in Modern Turkey." In Maqasid al-sharia and contemporary reformist Muslim thought: an examination, edited by Adis Duderija, Palgrave Macmillan, New York 2014.

Kutub, Seyyid, Fî Zilali'l-Kur'an, Daru'ş Şuruk, Kahire 1991.

Lassander, Mika, "Grappling with Liquid Modernity: Investigating Post-secular Religion", in Postsecular Society, edited by Peter Nynas, Mika Lassander, and Terhi Utriainen, Routledge, London and New York 2017.

Lyotard, Jean-François, The Postmodern Condition: A Report on Knowledge. Translated by Geoffrey Bennington, and Brian Massumi, and foreword by Fredric Jameson, University of Minnesota Press, Minneapolis 1984. [Postmodern Durum, çev. İsmet Birkan, Bilgesu Yay., İstanbul 2014].

March, Andrew, "The Maqșad of Hifz al-Dīn: Is Liberal Religious Freedom Sufficient for the Sharı̄'ah?" Islam and Civilizational Renewal, vol. 2, no. 2, 358-378, 2011.

McKenzie, Germán, Interpreting Charles Taylor's Social Theory on Religion and Secularization: A Comparative Study, Springer International Publishing, Vancouver BC 2017. 2016.

Nukaz, İsmail, Felsefetu't-Ta 'lil fî Fikri'l-İmameyn eş-Şâtıb̂̂ ve'd-Dihlevî, Mu'minune Bila Hudud,

Ramadan, Tariq, Radical Reform: Islamic Ethics and Liberation, Oxford University Press, New York 2009.

Raysuni, Ahmed, Nazariyyetu'l-Makâsıd 'inde'l-İmam Şâtıb̂, el-Ma'hedü'l-Alemî li'l-Fikri'lİslâmî, Virginia 1995.

Seyyid, Rıdvan, Makâsıdu'ş-Şerî‘ati fî Kitâbâti'l-Arabi'l-Muhaddisîn ve Muasırîn, fî̀ A 'mali Nedve Tatavvuru'l-Ulûmi'l-Fıkhiyye: el-Makâsıdu'ş-Şerî'a, Vizârâtu'l-Evkaf ve'ş-Şuûnu'd-Diniyye, Umman 2012.

Sztompka, Piotr, The Sociology of Social Change, Blackwell, Oxford 1993.

Şâtıbî, Ebu İshak, el-İtisam, Mektebetu't-Tevhid, t.y. [çev. Ahmet İyibildiren \& M. Özcan, İtisam Yay., İstanbul 2019].

Şâtıbî, Ebu İshak, el-Muvâfakât, Kahire, Daru İbn Affan, 1997, el-Muvâfakât fî Usûli'ş-Şerî'a, elMektebetu'l-Asriyye, Beyrut 2002. [çev. Mehmet Erdoğan, İz Yay., İstanbul 2016]. 2009.

Tayob, Abdulkader, Religion in Modern Islamic Discourse, Columbia University Press, New York

Tayyib, Ahmed, Nazariyyetu'l-Makâsıd 'inde'ş-Şâtıbî ve medâ İrtibatuha bi'l-Usûli'l-Kelamiyye, el-Müslimu'l-Muasır, 2002, 103.

Taân, Ahmed, el-Almaniyyun ve'l Kur'anu'l-Kerim, Daru İbn Hazm, Riyad 2007.

Wagner, Peter, Modernity as Experience and Interpretation: A New Sociology of Modernity, Polity Press, Cambridge 2008. [Deneyim ve Yorum Olarak Modernlik, çev. İbrahim Kaya, Pegem Akademi Yay., İstanbul 2014].

Wilson, Bryan R., Religion in Sociological Perspective, Oxford University Press, Oxford 1982.

Zerkeşî, Muhammed bin Abdullah, el-Bahru'l-Muhît fì Usûli'l-Fıkh, Daru'l-Kütübî, Kahire 1994. 